\title{
Correction: Legal Consciousness in Action: Lay People and Accountability in the Jury Room
}

\section{Matthew P. Fox ${ }^{1}$}

Published online: 6 November 2019

(C) Springer Science+Business Media, LLC, part of Springer Nature 2019

\section{Correction to: Qualitative Sociology https://doi.org/10.1007/s11133-019-09422-2}

The original version of this article unfortunately contained mistakes in Excerpts 6 and 8 in terms of text alignment. These mistakes were not present in the proofs provided to the author and were introduced during the final stages of article production.

The original article has been corrected.

Publisher's Note Springer Nature remains neutral with regard to jurisdictional claims in published maps and institutional affiliations.

The online version of the original article can be found at https://doi.org/10.1007/s11133-019-09422-2

Matthew P. Fox

mattfox@g.ucla.edu

1 Department of Sociology, University of California, Los Angeles, 264 Haines Hall, Box 951551, Los Angeles, CA 90095-1551, USA 